Journal of Information System, Informatics and Computing

Website/URL: http://journal.stmikjayakarta.ac.id/index.php/jisicom

Email: jisicom@stmikjayakarta.ac.id , jisicom2017@gmail.com

\title{
DESAIN KONSEP FINITE STATE AUTOMATA (FSA) PADA SIMULASI VENDING MACHINE (VM) MASAKAN PADANG
}

\author{
Syarif Hidayat ${ }^{1}$, Fadillah Said $^{2}$, Fakihotun Titiani ${ }^{3}$, \\ Windu Gata ${ }^{4}$ \\ Program Studi Ilmu Komputer 1,2,3,4 \\ Fakultas Ilmu Komputer $1,2,3,4$ \\ Universitas Nusa Mandiri ${ }^{1,2,3,4}$
}

14002411@ nusamandiri.ac.id ${ }^{1}$, 14002413@nusamandiri.ac.id ${ }^{2}$, 14002417@nusamandiri.ac.id ${ }^{3}$, windu@nusamandiri.ac.id ${ }^{4}$

Received: April 22, 2021. Revised: May 07, 2021. Accepted: May 22, 2021.

Published: June 20, 2021. Issue Period: Vol.5 No.1 (2021), Pp.134-143

\begin{abstract}
Abstrak: Teori bahasa dan automata merupakan teori yang berkaitan dengan mesin-mesin abstrak yang di dalamnya terdapat sebuah kajian tentang Finite State Automata (FSA) yang dapat diimplementasikan dalam rancangan sebuah Vending Machine (VM). VM di Indonesia banyak beroperasi dengan produk seperti minuman kaleng, minuman botol plastik, kopi, makanan ringan, dan tiket. Dalam penelitian ini, akan diuraikan mengenai aplikasi simulasi VM masakan padang sebuah produk makanan daerah yang terkenal di seluruh dunia dengan citarasa masakan yang beraneka ragam dan bumbu khas daerah sehingga memiliki kenikmatan luar biasa, berdasarkan implementasi FSA. Kesimpulan yang didapat dalam penelitian ini yaitu bahwa FSA dapat dijadikan sebagai logika dasar untuk membuat simulasi VM. Penelitian ini juga mengusulkan penggunaan state yang lebih sedikit, penggunaan uang kertas sebagai input untuk meningkatkan efisiensi dan biaya desain Vending Machine.
\end{abstract}

Kata kunci: Finite State Automata (FSA), Vending Machine (VM), Teori Bahasa dan Automata, Simulasi.

\begin{abstract}
Language and automata theory is a theory related to abstract machines in which there is a study of Finite State Automata (FSA) which can be implemented in the design of a Vending Machine (VM). VMs in Indonesia operate a lot with products such as canned drinks, plastic bottles, coffee, snacks, and tickets. In this research, we will describe the application of the simulation of Padang cuisine of a regional food product that is famous throughout the world with diverse cuisine and regional specialties so that it has extraordinary enjoyment, based on FSA implementation. The conclusion obtained in this study is that the FSA can be used as a basic logic for making VM simulations. This study also proposes the use of fewer states, the use of banknotes as input to increase the efficiency and cost of Vending Machine design.
\end{abstract}

Keywords: Finite State Automata (FSA), Vending Machine (VM), Language Theory and Automata, Simulation.

DOI: $10.52362 /$ jisicom.v5i1.442

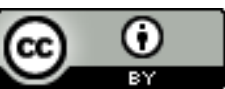

Ciptaan disebarluaskan di bawah Lisensi Creative Commons Atribusi 4.0 Internasional. 


\section{PENDAhUluan}

Rumah makan padang adalah rumah makan dengan konsep prasmanan yang menuntut seseorang untuk mengambil sendiri makanan yang ingin mereka makan sesuai dengan kebutuhan mereka[1]. Banyak rumah makan padang yang menawarkan masakan padang yang dengan harga yang murah meriah dengan rasa yang nikmat. Sehingga tidak jarang ada yang mempunyai loyalitas pelanggan terhadap suatu restoran tertento contohnya Restoran Sederhana Masakan Padang. Loyalitas pelanggan Restoran Sederhana Masakan Padang memiliki hubungan yang kuat[2]. Masakan Padang saat ini menjadi salah satu masakan yang paling popular di Indonesia maupun di mancanegara dan bahkan sudah menjadi masakan internasional. Masakan Padang yang terdiri dari resep dan menu masakan khas Padang, kelezatan cita rasa yang sangat digemari karena menggunakan resep rahasia keluarga dan bumbu-bumbu rempah tradisional yang dimiliki oleh orang asli Padang, akan tetapi masakan khas Padang tersebut belum banyak diketahui oleh masyarakat luas saat ini[3]. Banyaknya penyedia rumah makan padang yang terdapat di Jakarta saat ini menjadikan konsumen atau wisatawan kesulitan dalam memilih rumah makan yang diinginkan, oleh karena itu kami akan memberikan rekomendasi rumah makan berdasarkan nilai alternatif dari subkriteria yang diinginkan oleh konsumen[4].

Teori automata sangat erat kaitannya dengan mesin-mesin abstrak. Sedangkan teori bahasa erat kaitannya dengan komunikasi atau penghubung baik antara sesama manusia maupun dengan yang lainnya, jika diambil dalam materi ini maka bahasa adalah media antara manusia dengan komputer untuk saling berinteraksi [5]. Dari jenisnya yaitu Finite State Automata (FSA) terdapat mesin bahasa yang berarti dia dapat mengenali, menerima dan menolak yang terdapat pada mesin FSA jenis Deterministic Finite Automata (DFA) dan Nondeterministic Finite Automata (NFA)[6]. DFA dan NFA Merupakan mesin pada teori bahasa dan automata yang mudah untuk diaplikasikan dan sesuai dengan logika manusia. Pada DFA setiap simbol atau input hanya akan menuju ke satu state tertentu[7] .Dan ada FSA output yang mana berbeda dengan jenis FSA sebelumnya (DFA \& NFA), pada jenis ini tidak terdapat state menerima dan menolak, memiliki fungsi \& himpunan output [8]. Sebagai contoh mesin FSA output bisa dengan menggunakan simulasi Vending Machine (VM) yang mana konsep dasar dari alat tersebut adalah metode FSA output. Sebuah VM biasanya menjual 1 (satu) jenis barang, seperti : makanan ringan (snack), minuman, pembelian tiket seperti halnya di KRL, dan sebagainya[9]. Sebuah Vending Machine harus dapat melakukan proses transaksi penjualan yang sesuai berdasarkan pilihan yang diberikan pengguna dan dapat mengatasi permasalahan dalam VM maka akan digunakan penerapan konsep FSA pada VM untuk memodelkan proses transaksi secara otomatis[10]. Walaupun di Indonesia, khususnya Jakarta sudah banyak penggunaan VM, namun terlintas dalam benak untuk mengetahui dan mempelajari proses dari VM tersebut[11].

Sedangkan Ilmu komputer memiliki dua komponen utama, pertama, model dan gagasan mendasar mengenai komputasi, kedua, teknik rekayasa untuk perancangan sistem komputasi, meliputi perangkat keras dan perangkat lunak, khususnya penerapan rancangan dari teori. Teori bahasa dan automata merupakan bagian pertama. Teori Bahasa dan Automata banyak diterapkan pada perancangan digital, pembuatan bahasa pemrograman, dan kompilator[12]. Automata adalah suatu bentuk yang memiliki fungsi-fungsi dari komputer digital. Menerima masukan, menghasilkan keluaran, bisa memiliki penyimpan sementara, dan mampu membuat keputusan dalam mentransformasikan masukan ke keluaran. Automata merupakan suatu sistem yang terdiri atas sejumlah state berhingga, dimana setiap state menyatakan informasi mengenai input sebelumnya, dan dapat pula dianggap sebagai memori mesin. Input pada mesin automata dianggap sebagai bahasa yang harus dikenali oleh mesin. Selanjutnya mesin automata membuat keputusan yang mengindikasikan diterima atau tidaknya input tersebut, sehingga mesin automata dapat dipakai untuk menghasilkan suatu bahasa yang aturannya ditentukan oleh bahasa tersebut. Teori automata sangat erat kaitannya dengan mesin-mesin abstrak. Sedang teori bahasa erat kaitannya dengan komunikasi atau penghubung baik antara sesama manusia maupun dengan yang lainnya, jika diambil dalam materi ini maka bahasa adalah media antara manusia dengan komputer untuk saling berinteraksi[13]. FSA/state automata berhingga, selanjutnya disebut sebagai FSA, bukanlah mesin fisik tetapi suatu model matematika dari suatu sistem yang menerima input dan output diskrit[14]. FSA memiliki state yang banyaknya berhingga, dan dapat berpindah-pindah dari satu state ke state lain. Perubahan state ini dinyatakan dengan fungsi transisi. State adalah kondisi atau keadaan atau kedudukan. FSA adalah model matematika yang

DOI: $10.52362 /$ jisicom.v5i1.442

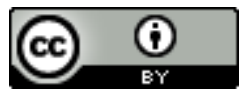

Ciptaan disebarluaskan di bawah Lisensi Creative Commons Atribusi 4.0 Internasional. 
dapat menerima input dan mengeluarkan output yang memiliki state yang berhingga banyaknya dan dapat berpindah dari satu state ke state lainnya berdasarkan input dan fungsi transisi[12]. Perkembangan VM di Indonesia masih sangat muda. Berdasarkan data yang tercantum dalam Jurnal "Pemodelan VM dengan Metode FSA (Finite State Automata)'"[15].

VM yang dapat menerima sistem pembayaran uang elektronik, contohnya e-money, flash, dan kartu elektronik lainya akan semakin popular dan semakin diterima di masyarakat. Keberadaan VM pastinya akan terus bertambah lagi dengan banyaknya variasi ataupun pilihan jenis barang yang diberikan dan bermacam macam nominal baik uang kertas maupun uang koin. Sebuah VM harus dapat melakukan proses transaksi penjualan yang sesuai berdasarkan pilihan yang diberikan pengguna. Untuk mengatasi permasalahan dalam VM maka akan digunakan penerapan konsep FSA pada VM untuk memodelkan proses transaksi secara otomatis. Berbagai metode teknologi yang efisien dari segi waktu pengembangan maupun penggunaan dalam perancangan VM terus berkembang dan dikaji sampai sekarang. Persebaran VM di Indonesia untuk saat ini, masih memusat di perkotaan, itu pun di tempat-tempat yang keamanannya terjamin. Rasanya sulit bila VM menyebar ke segala penjuru[15]. Penelitian mengenai implementasi FSA dalam pengembangan VM terus dilakukan baik dari analisis terhadap VM yang sudah ada, seperti pada penelitian yang dilakukan oleh Jessica[14], dari sisi perancangannya, seperti pada penelitian oleh Bhonde[16], Alrehily[17] dan Abhisek[18]. Sedangkan dalam hal lexical analysis berikut desainnya telah dibahas oleh Ezhilarasu[19], maupun simulasinya oleh Saputra[13] dan Jessica[14] dan Megimplemntasikan FSA terintergrasi dengan E-KTP FSA diterapkan pada penjualan rokok otomatis atau VM[20].

Dalam penelitian ini dibuat sebuah aplikasi simulasi VM yang dapat melakukan proses transaksi penjualan Masakan Padang seharga dua puluh ribu rupiah. Aplikasi ini membutuhkan input berupa uang dan rasa lauk apa yang dipilih, sedangkan outputnya adalah enam macam lauk masakan padang (ayam bakar, ayam pop, rendang, tunjang, gulai kepala kakap, dan nasi) sesuai dengan pilihan pengguna. Uang yang digunakan adalah nominal dua puluh rupiah, atau yang jumlahnya dua puluh rupiah. Tujuan dari penelitian ini adalah menerapkan konsep Finite State Automata (FSA) pada aplikasi simulasi Vending Machine Masakan Padang. Penerapan konsep FSA dipilih karena automata terbatas adalah mesin yang lebih sederhana, yang awalnya diusulkan untuk dimodelkan fungsi otak manusia[19].

\section{METODE DAN MATERI}

Metode yang digunakan dalam pelaksanaan penelitian ini adalah formal methods. Formal methods atau metode formal, dalam ilmu komputer dan rekayasa perangkat lunak, adalah suatu pemodelan matematika, yang dapat digunakan untuk menjembatani (spesifikasi formal) pembuatan, pengembangan dan verifikasi perangkat keras dan piranti lunak, yang dapat digunakan dari perancangan awal sampai pengujian hasil.[21]

Sebagaimana pada gambar dibawah ini yang diselesaikan melalui empat tahapan, yaitu : (1) Pertama melakukan pemahaman terkait dengan VM dan penjualan masakan padang, (2) Perancangan sistem, (3) Perancangan diagram state VM, dan (4)Pengujian Sistem dan analisis hasil pengujian.

DOI: $10.52362 /$ jisicom.v5i1.442

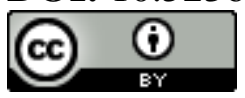

Ciptaan disebarluaskan di bawah Lisensi Creative Commons Atribusi 4.0 Internasional. 
e-ISSN : 2597-3673 (Online), p-ISSN : 2579-5201 (Printed)

Vol.5 No.1 Juni 2021

Journal of Information System, Informatics and Computing

Website/URL: http://journal.stmikjayakarta.ac.id/index.php/jisicom

Email: jisicom@stmikjayakarta.ac.id, jisicom2017@gmail.com

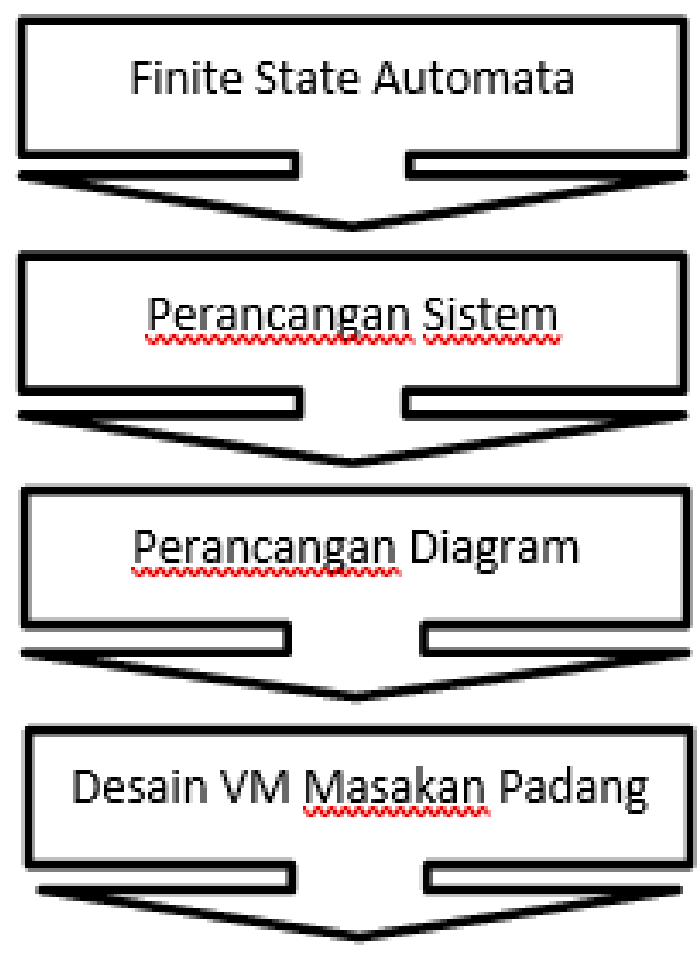

Gambar 1. Tahapan Penelitian

Activity diagram menggambarkan sebuah alur dari rangkaian kegiatan yang ada pada sistem yang sedang dirancang tergambar seperti pada gambar 2.

DOI: $10.52362 /$ jisicom.v5i1.442

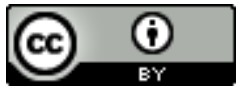

Ciptaan disebarluaskan di bawah Lisensi Creative Commons Atribusi 4.0 Internasional. 
e-ISSN : 2597-3673 (Online), p-ISSN : 2579-5201 (Printed)

Vol.5 No.1 Juni 2021

Journal of Information System, Informatics and Computing

Website/URL: http://journal.stmikjayakarta.ac.id/index.php/jisicom

Email: jisicom@stmikjayakarta.ac.id , jisicom2017@gmail.com

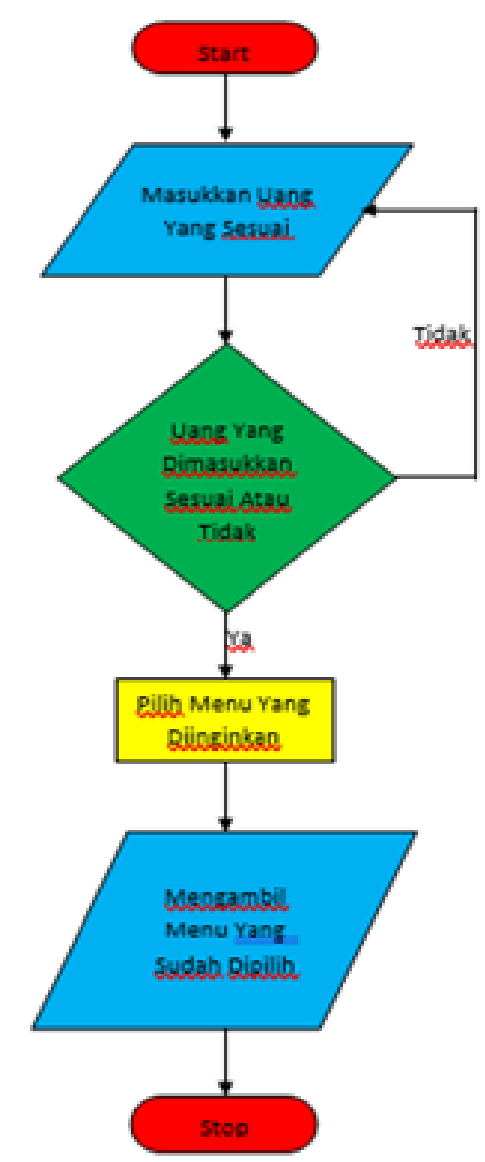

Gambar 2. Activity Diagram

\section{PEMBAHASAN DAN HASIL}

a. Input yang digunakan berupa uang kertas nominal dua puluh rupiah, atau yang jumlahnya dua puluh rupiah dan adalah enam macam lauk masakan padang (ayam bakar, ayam pop, rendang, tunjang, gulai kepala kakap, dan nasi). Berdasarkan batasan tersebut, maka dapat dibuat diagram state seperti pada Gambar 3.

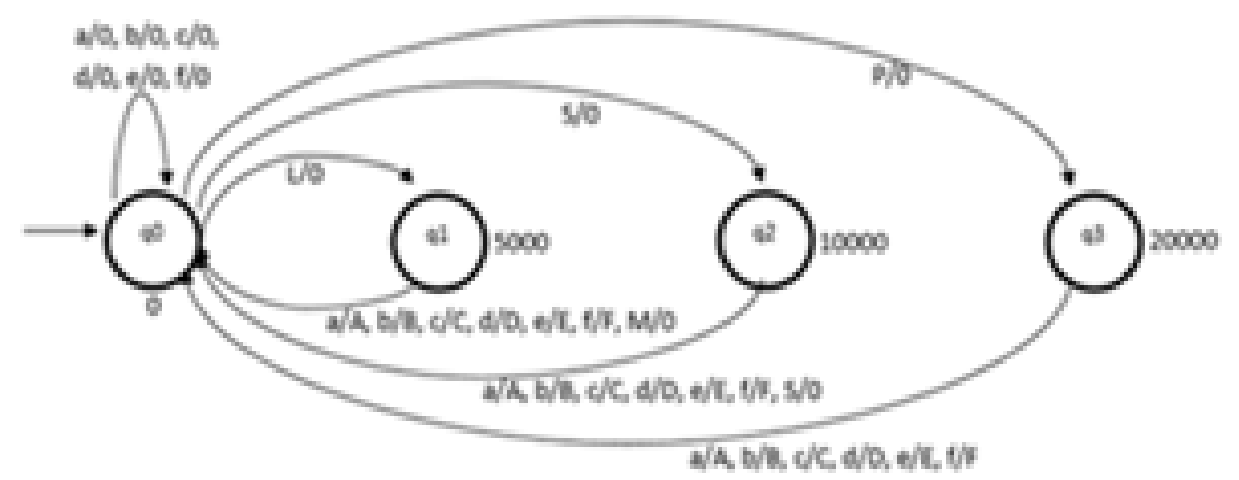

Gambar 3. Rancangan diagram transisi aplikasi simulasi Vending Machine Masakan Padang

DOI: $10.52362 /$ jisicom.v5i1.442

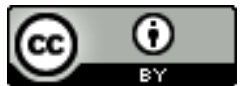

Ciptaan disebarluaskan di bawah Lisensi Creative Commons Atribusi 4.0 Internasional. 
Journal of Information System, Informatics and Computing

Website/URL: http://journal.stmikjayakarta.ac.id/index.php/jisicom

Email: jisicom@stmikjayakarta.ac.id , jisicom2017@gmail.com

Pendefinisian Tuple

Mealy machine didefinisikan dengan enam tupel.

$\mathrm{M}=(\mathrm{Q}, \Sigma, \square, \mathrm{S}, \Delta, \square)$

dengan:

Q: himpunan state

$\Sigma$ : himpunan simbol input

$\square$ : fungsi transisi

S: state awal

$\Delta$ : himpunan simbol output

$\square$ : fungsi output.

Sehingga dapat didefinisikan sebagai berikut:

$\mathrm{Q}=\{\mathrm{q} 0, \mathrm{q} 1, \mathrm{q} 2, \mathrm{q} 3\}$

$\Sigma=\{\mathrm{a}, \mathrm{b}, \mathrm{c}, \mathrm{d}, \mathrm{e}, \mathrm{f}, \mathrm{L}, \mathrm{S}, \mathrm{P}\}$

$\mathrm{S}=\{\mathrm{q} 0\}$

$\Delta=\{\mathrm{A}, \mathrm{B}, \mathrm{C}, \mathrm{D}, \mathrm{E}, \mathrm{F}, \mathrm{O}\}$

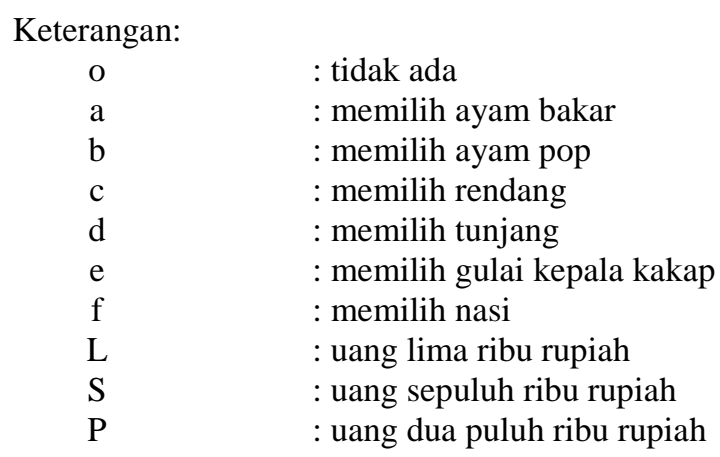

Terdapat sembilan input pada mesin ini, yaitu a (memilih ayam bakar), b (memilih ayam pop), c (memilih rendang), d (memilih tunjang), e (memilih gulai kepala kakap), f (memilih nasi), L (uang lima ribu rupiah), $\mathrm{S}$ (uang sepuluh ribu rupiah), P (uang dua puluh ribu rupiah). Sedangkan outputnya ada enam, antara lain A (mengeluarkan ayam bakar), B (mengeluarkan ayam pop), C (mengeluarkan rendang), D (mengeluarkan tunjang), E (mengeluarkan gulai kepala kakap), F (mengeluarkan nasi).

Diagram transisi tersebut menggambarkan spesifikasi proses yang terdapat pada Vending Machine Masakan Padang yang menerapkan konsep FSA. Mesin akan mengikuti pola alur dari proses transaksi penjualan makanan sesuai dengan pilihan lauk yang tersedia. Selanjutnya dilakukan proses mengeluarkan makanan sesuai dengan bahasa yang dibaca.

b. Sebuah use case diagram berfungsi untuk mendeskripsikan tindakan sistem dari sudut pandang pengguna, sebagai deskripsi fungsional dari sebuah sistem dan proses utamanya, serta menjelaskan secara visual siapa yang menggunakan sistem dan bagaimana interaksinya. Use case diagram untuk pengguna dapat dilihat pada Gambar 4.

DOI: $10.52362 /$ jisicom.v5i1.442

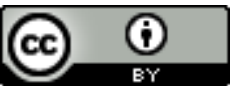

Ciptaan disebarluaskan di bawah Lisensi Creative Commons Atribusi 4.0 Internasional. 
e-ISSN : 2597-3673 (Online), p-ISSN : 2579-5201 (Printed)

Vol.5 No.1 Juni 2021

Journal of Information System, Informatics and Computing

Website/URL: http://journal.stmikjayakarta.ac.id/index.php/jisicom

Email: jisicom@stmikjayakarta.ac.id , jisicom2017@gmail.com

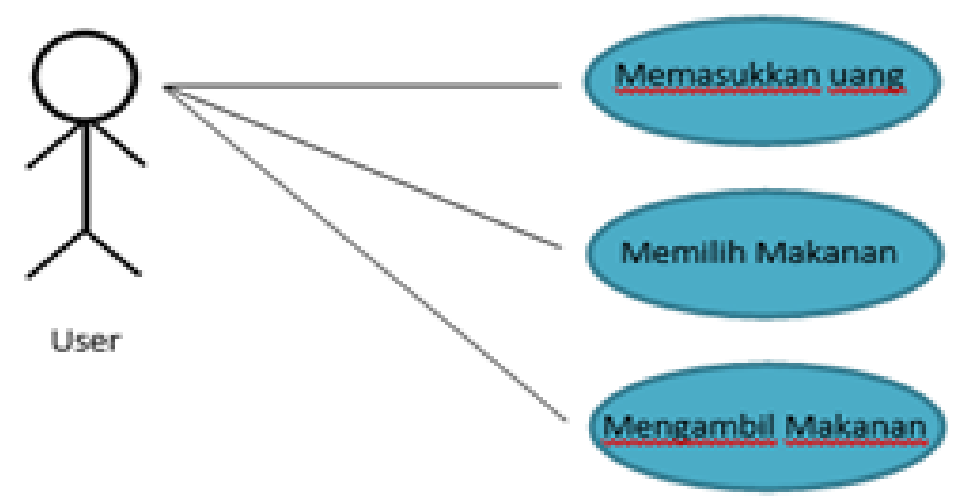

Gambar 4. Use case diagram untuk pengguna

Setelah melakukan spesifikasi maka tahap selanjutnya adalah implementasi. Spesifikasi formal yang telah ditentukan sebelumnya kemudian diimplementasikan kedalam suatu kode program yang menerapkan konsep FSA didalam kode program tersebut.

c. Pada penelitian ini teknik verifikasi formal yang digunakan adalah model checking. Dalam pengujian ini diuji apakah desain memang seperti yang diharapkan.

Pada simulasi Vending Machine masakan padang diterapkan konsep FSA untuk pemodelan proses penjualan masakan padang secara otomatis. Hasil simulasi mempunyai tampilan Vending Machine masakan padang ditunjukkan pada Gambar 5.

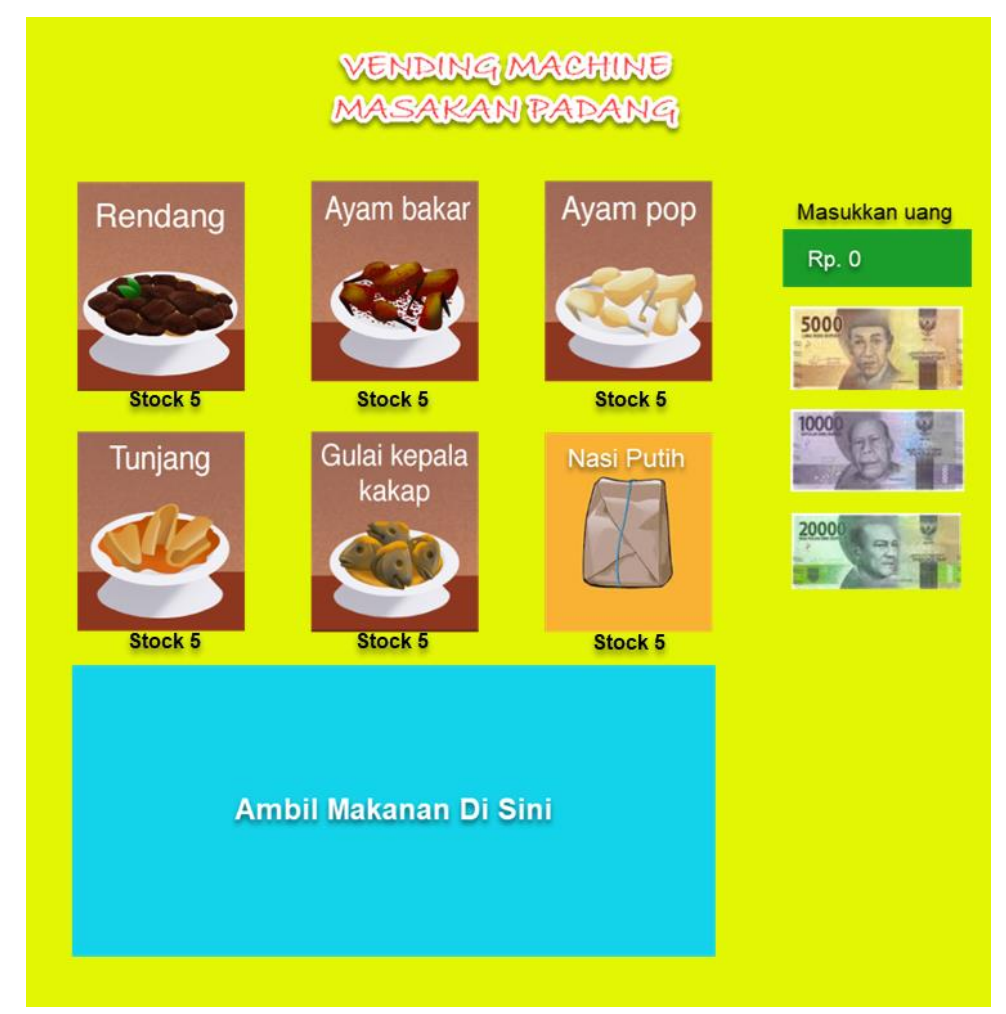

DOI: $10.52362 /$ jisicom.v5i1.442

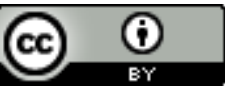

Ciptaan disebarluaskan di bawah Lisensi Creative Commons Atribusi 4.0 Internasional. 
Journal of Information System, Informatics and Computing

Website/URL: http://journal.stmikjayakarta.ac.id/index.php/jisicom

Email: jisicom@stmikjayakarta.ac.id, jisicom2017@gmail.com

Gambar 5. Tampilan simulasi VM masakan padang

Pengguna memasukkan uang dengan cara drag drop. Lalu VM akan membaca nilai uang yang dimasukkan. Kemudian pengguna memilih masakan yang diinginkan. Jika pengguna memasukan uang dua puluh ribu rupiah lalu memilih masakan rendang, maka mesin akan mengeluarkan masakan rendang dan stok masakan rendang berkurang satu. Tampilan aplikasi ditunjukkan pada Gambar 6.

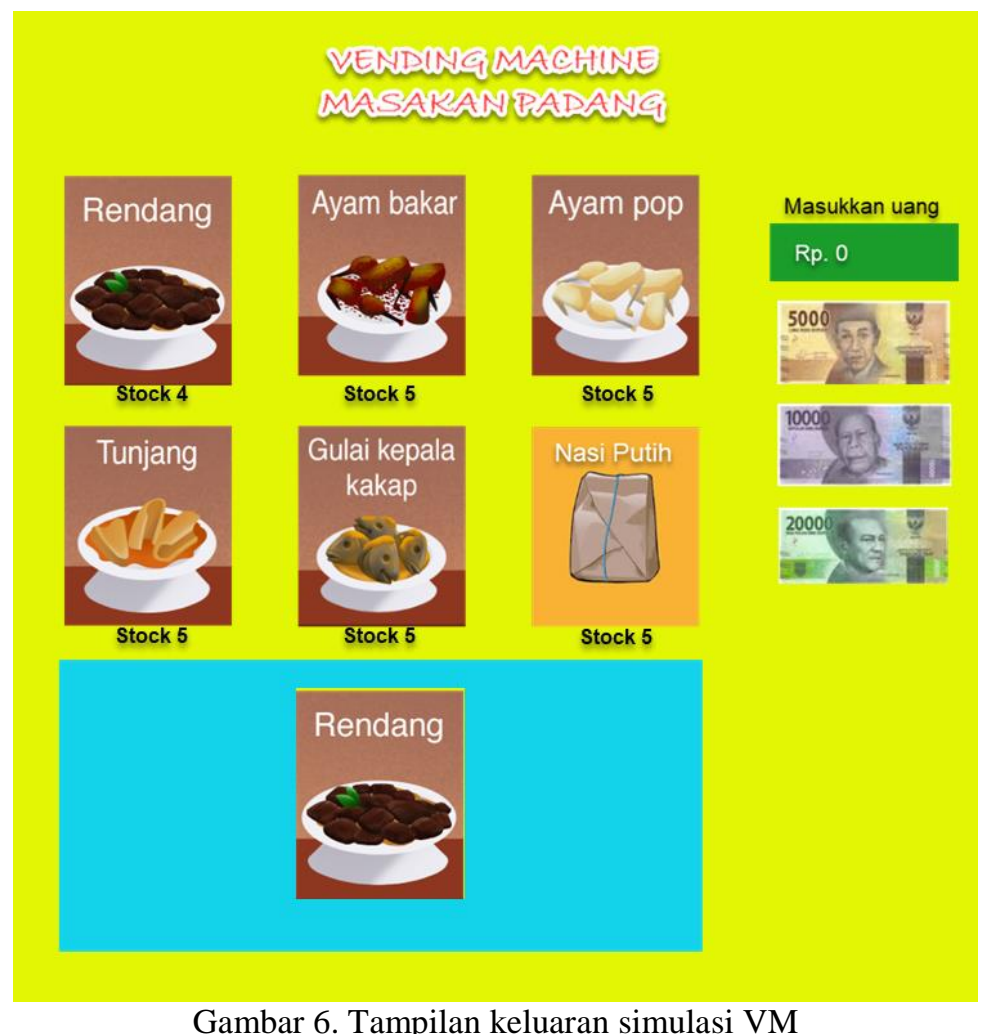

Setelah implementasi, aplikasi selanjutnya diuji apakah sesuai dengan rancangan atau tidak. Hasil dari pengujian yang dilakukan ditunjukkan pada Tabel 1 .

Tabel 1. Daftar hasil penguiian aplikasil

\begin{tabular}{llc}
\hline No & \multicolumn{1}{c}{ Penguiian } & Keterangan \\
\hline 1 & Kesesuaian output dengan input pilihan menu masakan yang diberikan & Baik \\
2 & Kesesuaian output dengan uang yang dimasukkan & Baik \\
3 & Pengurangan stok masakan & Baik \\
4 & Pengisian stok makanan & Baik \\
5 & Pemberitahuan informasi iika menu masakan yang dipilih hakis & Baik \\
\hline
\end{tabular}

DOI: $10.52362 /$ jisicom.v5i1.442

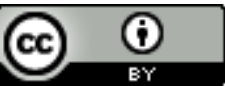

Ciptaan disebarluaskan di bawah Lisensi Creative Commons Atribusi 4.0 Internasional. 


\section{KESIMPULAN}

FSA dapat menjadi logika dasar untuk merancang suatu VM yang fleksibel dalam proses penjualan Masakan Padang dengan berbagai lauk. Konsep FSA pada VM diterapkan dengan cara FSA membaca setiap simbol masukan yang diberikan menjadi suatu bahasa yang dikenali oleh FSA. Mesin selanjutnya akan melakukan proses pengeluaran masakan padang berdasarkan lauk yang diinginkan sesuai dengan bahasa yang telah dibaca oleh FSA. Penerapan konsep FSA dapat menjadi salah satu alternatif untuk merancang sebuah VM serta dapat dijadikan bahan pertimbangan dan acuan untuk pengembangan aplikasi selanjutnya yang sejenis.

\section{REFERENSI}

[1] O. Zakaria and Kusrini, "Implementasi Data Mining Terhadap Penyusunan Layout Makanan pada Rumah Makan Padang 'Murah Meriah,”' Semin. Nas. Teknol. Inf. dan Multimed. 2013, 2013.

[2] R. Wahyuni and H. Irfani, "Pengaruh Relationship Marketing, Kepuasan Dan Brand Image Terhadap Loyalitas Pelanggan Restoran Sederhana Masakan Padang," J. EKOBISTEK Fak. Ekon., 2017.

[3] F. Evi and Hamsyah, "Penerapan Metode Forward Dan Backward Chaining Dalam Sistem Pakar Pemilihan Resep Masakan Khas Padang,” J. STMIK PalComTech, 2016.

[4] E. Yulianti and F. Juwita, "Jurnal TEKNOIF ISSN : 2338-2724 Sistem Pendukung Keputusan Pemilihan Tempat Kuliner di Kota Padang Menggunakan Metode Perbandingan Eksponensial (MPE) ( MPE ) Jurnal TEKNOIF ISSN : 2338-2724,” J. TEKNOIF, 2016.

[5] V. V. S. V. Krishna, A. Monisha, S. K. Sadulla, and J. Prathiba, "Design and implementation of an automatic beverages vending machine and its performance evaluation using Xilinx ISE and Cadence," 2013, doi: 10.1109/ICCCNT.2013.6726639.

[6] K. Kim, D. H. Park, H. Bang, G. Hong, and S. Il Jin, "Smart coffee vending machine using sensor and actuator networks," 2014, doi: 10.1109/ICCE.2014.6775913.

[7] A. Ardiansyah, N. Hardi, and W. Gata, "Identifikasi dan Recovery File JPEG dengan Metode Signature-Based Carving dalam Model Automata,” Komputika J. Sist. Komput., 2020, doi: 10.34010/komputika.v9i1.2733.

[8] S. M. S. Arifin et al., "Smart vending machine based on SMS gateway for general transactions," 2017, doi: 10.1109/QIR.2017.8168447.

[9] N. Kulmukhanova, A. Daribay, I. Temirtayev, and U. Bassembek, "ZhardEM Medicine Vending Machine," 2018, doi: 10.1109/CoCoNet.2018.8476912.

[10] R. Suharsih and F. Atqiya, "Penerapan Konsep Finite State Automata (FSA) pada Aplikasi Simulasi Vending Machine Yoghurt Walagri," Pendidik. Multimed., 2019.

[11] W. Cui, Y. Huang, and M. Liu, "Influential Factors of Vending Machine Interface to Enhance the Interaction Performance," 2016, doi: 10.1109/ICICTA.2015.285.

[12] T. Bahasa, D. a N. Otomata, and J. T. Informatika, “Teori bahasa dan otomata,” Univ. Stuttgart, 2004.

[13] T. I. Saputra, F. Fauziah, and A. Gunaryati, "Simulasi Vending Machine Dengan Mengimplementasikan Finite State Automata," JOINTECS (Journal Inf. Technol. Comput. Sci., 2018, doi: 10.31328/jointecs.v3i3.819.

DOI: $10.52362 /$ jisicom.v5i1.442

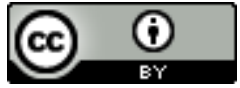

Ciptaan disebarluaskan di bawah Lisensi Creative Commons Atribusi 4.0 Internasional. 
e-ISSN : 2597-3673 (Online) , p-ISSN : 2579-5201 (Printed)

Vol.5 No.1 Juni 2021

Journal of Information System, Informatics and Computing

Website/URL: http://journal.stmikjayakarta.ac.id/index.php/jisicom

Email: jisicom@stmikjayakarta.ac.id, jisicom2017@gmail.com

[14] J. C. Irawan, I. M. A. Pakereng, and R. Somya, "Perancangan dan Implementasi Finite Automata pada Simulasi Vending Machine," d'CARTESIAN, 2012, doi: 10.35799/dc.1.1.2012.534.

[15] T. H. Wicaksono, F. D. Amrizal, and H. A. Mumtahana, "Pemodelan Vending Machine dengan Metode FSA ( Finite State Automata )," DoubleClick J. Comput. Inf. Technol., 2019.

[16] P. V. Bhonde, "Review on Design Simulation of Smart Vending Machine Using FPGA," Int. J. Res. Appl. Sci. Eng. Technol., 2018, doi: 10.22214/ijraset.2018.4259.

[17] A. Alrehily, R. Fallatah, and V. Thayananthan, "Design of Vending Machine using Finite State Machine and Visual Automata Simulator,” Int. J. Comput. Appl., 2015, doi: 10.5120/20254-2623.

[18] A. Luthra, A. Jain, P. Mishra, V. Gupta, and S. Aggarwal, "Design and Implementation of Vending Machine using Verilog HDL on FPGA," Int. J. Innov. Res. Sci. Eng. Technol. (An ISO Certif. Organ., 2007, doi: 10.15680/IJIRSET.2015.0411137.

[19] P. Ezhilarasu and N. Krishnaraj, "Applications of Finite Automata in Lexical Analysis and as a Ticket Vending Machine - A Review,” Int. J. Comput. Sci. Eng. Technol., 2015.

[20] W. G. Gabriel Vangeran Saragih, Anas Faisal, "Desain Vending Machine Rokok Dengan Mengimplementasikan Finite State Automata," Desain Vend. Mach. Rokok Dengan Mengimplementasikan Finite State Autom. Terintegrasi Dengan E-KTP, 2020.

[21] Wamiliana, D. Kurniawan, and R. I. M. E. P., "Penerapan Konsep Finite State Automata (FSA) pada Mesin Pembuat Minuman Kopi Otomatis,” Komputasi, 2013.

DOI: $10.52362 /$ jisicom.v5i1.442

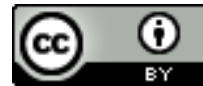

Ciptaan disebarluaskan di bawah Lisensi Creative Commons Atribusi 4.0 Internasional. 